\title{
Requests in Saudi Pidgin Arabic
}

\author{
Hessah Al-Ageel \\ School of Global, Urban and Social Studies \\ RMIT University, Melbourne, Australia \\ E-mail: alageelh10@gmail.com
}

Received: May 27, 2015 Accepted: June 10, 2015 Published: June 30, 2015

doi:10.5296/bms.v6i1.7682ＵRL: http://dx.doi.org/10.5296/bms.v6i1.7682

\begin{abstract}
This study aims to investigate Saudi Pidgin Arabic (SPA) as one of the linguistic varieties that has emerged as a result of the interaction between Saudis and Asian workers. Linguistic and sociolinguistic analysis has been conducted for requestive expressions made by two generations of Saudi female speakers to female Asian workers in the cafeteria of a governmental institute in Riyadh, Saudi Arabia. The study shows that the use of SPA is largely limited to the simplest forms of verb and noun phrases that are used in Najdi Arabic (the variety that is used in the middle region of Arabian Peninsula), the lexifier language of SPA. The impact of English on the younger generation is shown by the tendency of younger participants to employ English expressions. A sociolinguistic analysis also shows the impact of the social variables of power, status, social distance and the age of the requester.
\end{abstract}

Keywords: Pidgin, Saudi Pidgin Arabic (SPA), Gulf Arabic Pidgin (GPA), sociolinguistics, Linguistic analysis 


\section{Introduction}

Ferguson (1971) refers to pidgins and creoles as simplified speech used to communicate with people who are considered unable to understand normal speech, such as babies or foreigners. One of the essential points that should be clarified in this context is the link between the term pidgins. This linguistic variety is used in the contact between two speech communities from two different linguistic backgrounds (Al-Azraqi 2010; Al-Moaily, 2008).Bresnan and Roberts (2008:272) state that pidgins 'develop as auxiliary languages and thus lack native communities, at least initially'.

Although the contact is between two languages, the vocabulary of a pidgin comes particularly from one dominant language called the 'lexifier' or 'superstrate', while the non-dominant language is called the substrate (Al-Moaily, 2008; Bizri, 2009; Al-Azraqi, 2010). Pidgins also do not have a stable grammatical structure and they are usually used specifically among adults for a short period of time (Al-Azraqi, 2010). However creoles are classified as more developed and as a mother tongue, with an expansive use of vocabulary and a more stable grammatical structure (Al-Moaily, 2008; Al-Azraqi, 2010). Pidgins can be seen as creoles when they are used by children as their native tongue and when they enable their native speakers to produce the utterances necessary for their daily communication (Al-Moaily, 2008; Al-Azraqi, 2010). It can be said that the birth of pidgins and creoles in languages is usually associated with several factors, or purposes, such as trade, migration and colonization, in addition to an international mobile work force (Bickerton, 1983; Al-Azraqi, 2010). For example, while some pidgins such as Nigerian and Cameroon Pidgin English were used in trade, creoles such as Cape Verdian Criolou, lexified by Portuguese, were established in colonial settlements for agricultural purposes (Bickerton, 1983; Al-Azraqi, 2010).

\section{Saudi Pidgin Arabic}

This study focuses on the spoken variety that is used by native speakers of Saudi Arabic when they communicate with non-native speakers of Arabic, specifically Asian workers. This linguistic phenomenon will be referred as Saudi Pidgin Arabic (hereafter SPA), since this form of spoken Arabic meets the main features of pidgins. SPA is not a native language and is used as a communicative means mainly by adults for a short period of time for a specific purpose, i.e. work or trade. According to Ferguson (1971), in the Arabic-Armenian context, one of the linguistic features used in Arabic is the use of the third person masculine singular of the imperfect of the verb, which stands for the present tense in Arabic, for all persons, genders, numbers and tenses. For example, the form ' $y$ a'rif' is used for 'he knows', 'she knows' and 'you know'; and this linguistic feature is also common in Pidgin Arabic during contact with non-native speakers from other linguistic backgrounds.

A number of historical, social and sociolinguistic issues that surround the linguistic phenomenon of Saudi Pidgin Arabic. One complicating terminological factor is that, for some reason, pidgin in Gulf spoken Arabic has not been referred to consistently in the literature. For example, it is called Gulf Asian Pidgin (GAP) in Al-Azraqi (2010) because it is 
specifically used in contact with Asian workers. On the other hand, Smart (1990) and Wiswall (2002) use the more generalised term Gulf Pidgin (GP) to describe this phenomenon because it may include English in some cases of daily communication. To avoid complexity and confusion in describing this variety, Gulf Pidgin Arabic (GPA), as used by Naess (2008), will be used in the current context interchangeably with SPA, since Saudi spoken Arabic linguistically, historically and regionally shares the features of Gulf spoken Arabic.

Social life in Saudi Arabia has been affected by the dramatic changes that have occurred in the last few decades as a result of being one of the richest oil countries since 1938 (Al-Azraqi, 2010). After several decades and as a result of government development programs, workers from different parts of Asia started to arrive in Saudi Arabia and other Gulf countries to contribute to the growing of the infrastructure and to provide assistance in domestic work (Wiswall, 2002; Al-Azraqi, 2010). As a result of the contact between the speakers of Saudi Arabic and Asian workers who are non-native speakers of Arabic, SPA has emerged as a new linguistic variety.

As in other Gulf countries, it can be seen that the use of SPA is significantly associated with social dimensions such as power status and social distance. The dimension of power distance is evident in the contact between Asian workers and their Saudi employers, while a reflection of the social distance, and possibly also power and status, appears in the contact between local Saudi and foreign workers in shops, markets or any other institutions (Smart, 1990). In other words, it can be said that the social gap between the local population in Gulf countries and the immigrant Asian workers was one of the factors that significantly contributed to the emergence of GPA. In this situation, the dominant group might create a register to address speakers of the non-dominant group in order to keep them culturally isolated and to maintain the social distance between the two groups (Naess, 2008).

There is not a great deal of literature on Arabic-based pidgins. However, Smart (1990), in one of the pioneer studies on pidgin in Gulf countries, finds that the geographical area with the most widespread use of this variety is along the Gulf coast line from Oman to Kuwait, including the coastline of Saudi Arabia. The corpus of his study was drawn from newspaper cartoon captions written by Arabic speakers imitating the pidgin produced by foreign workers. The work of Smart was later criticized by Wiswall (2002) because the data was insufficient and limited to the variety produced by native speakers of Arabic. For this reason, Wiswall (2002) provides a wider range for his corpus by proposing that there is considerable variation in the use of GPA that is characterized by Arabic speakers' performance as superstrate and Indian speakers' performance as substrate.

In a different context, Bizri (2009) discusses the variety used between Sri Lankan female domestic workers and their Lebanese female employers. She refers to this situation as 'Pidgin Madam' since the domestic workers use Madam to refer to their Lebanese employers. Here Lebanese Arabic (LA) is the lexifier or the superstrate and Colloquial Sinhala (CS) is the substrate. According to Bizri (2009), although Pidgin Madam has not reached a stable stage of language, it is distinguished by several grammatical and linguistic features. It shows, for 
instance, an extensive use of Arabic imperatives as verbal stems. According to Bizri (2009), Sri Lankan domestic workers use LA imperatives for their affirmative present or past tenses. For example, to express the meaning of 'I am going to sleep', or 'I want to go to sleep', a Sri Lankan worker may use ana ruyi nemi, 'I do go to sleep'. The verb ruyi 'go' is used for imperatives in LA. This frequent use of LA imperatives in the singular feminine form also reflects a degree of the social power status, since imperatives are used by female speakers of LA to address Sri Lankan domestic workers (Bizri, 2009). However, Bizri (2009) claims that Pidgin Madam is also used among native Arabic speakers for other purposes such as in comic situations, to express jokes or to claim innocence.

To determine whether Gulf Pidgin Arabic could formally be considered a separate variety, Naess (2008) examined the linguistic features of GPA. She collected her data in Oman and the United Arab Emirates through interviews with Asian migrant workers. An analysis of its grammatical features would appear to suggest that GPA is a variety on the way to becoming conventionalized as a first-generation contact language. Naess (2008) also claims that although GPA is much less standardized than other Arabic-bases pidgins, it has a degree of stability. For this reason, she suggests that this variety should be classified as an incipient pidgin variety.

Another study conducted by Al-Azraqi (2010) examined the syntactic features of Gulf Asian Pidgin. Data for this study were collected in GPA from both native Arabic speakers and Asian migrant workers in Saudi Arabia. She found that some Arabic grammatical features are used in GPA; however, the word order and the use of some particles is different from Gulf Arabic, the lexifier.

\section{Politeness Strategies from a Sociolinguistic Perspective}

In addition to the linguistic analysis for SPA, the current study focuses on some aspects of politeness behavior in making requests to non-native speakers of Arabic, specifically Asian workers, for the purpose of reflecting some sociolinguistic dimensions of requesting behavior within this context. One of the best-known works in the area of politeness and social interaction is Brown and Levinson's (1987) model of face and linguistic politeness. Brown and Levinson's model classifies speech acts into four categories: most direct, conventionally indirect, non-conventionally indirect and opting out. This classification is subject to various factors, and these factors include the power that the speaker has over the hearer, the social distance between interlocutors, and the degree of imposition involved. Requests are 'face threatening acts' that threaten the hearer's negative face, since the speaker is required to employ various strategies to mitigate the force of such a speech act (Brown and Levinson, 1987).

Another important classification system, based on the work of Brown and Levinson, is the Cross Cultural Speech Act Realization Project, CCSAR (Blum-Kulka, House \& Kasper, 1989). This classification system refers to requests as 'head acts' that are usually employed according to the directness level. In addition, head acts are usually accompanied with what is 
known as internal and external modifications. While internal modifications include interrogatives and other linguistic expressions that are used to soften the force of requests, such as politeness markers (please and excuse me) or religious expressions, external modifications, on the other hand, are the peripheral elements that are commonly used for the same purpose. These external modifications are used to soften the force of requests, as in preparators (Can I ask you a favour?), grounders (Can you help me carry these things because they are a bit heavy), and small talk (Good morning John, how are you? Is everything fine? I really need your help) (Félix-Brasdefer, 2005).

In the Arabic context, the internal modifications mumkin? 'is it possible?' and law samahtii 'would you mind' are amongst the most common mitigators employed to show higher level of politeness in the context of requests.

\section{Data and Methodology}

The study used a combination of interview and naturalistic recorded interactions. Both of these data gathering methods were based in a large government educational institute in Riyadh, Saudi Arabia. Authentic audiorecorded data was collected via a telephone, which was used to record conversations between Saudi female participants requesting breakfast and female cafeteria Asian workers. (Note that the data only included the speech of the Saudi women, not the Asian cafeteria workers, because permission was only granted to record the voices of the Saudi participants). Within a period of three weeks, the researcher also interviewed sixteen participants drawn from staff and trainees of the organization: eight participants aged 20-39 and eight aged 40-60. The reason for differentiating between the two age groups was to determine whether there is an impact of age on the use of SPA amongst female native speakers of Saudi Arabic.

One of the significant advantages of collecting natural conversations in a social context is to maximise validity (Boxer, 1993). In addition, using this method provides the researcher with data rich in semantic features, diversity and length (Hartford \& Bardovi-Harlig, 1992; Beebe \& Cummings, 1996; Al-Gahtani, 2010). This method has also been criticized for failing to control for social variables when analysing speech acts (Tran, 2004). Since the social variables are stable in this study - the speaker has a higher status than the hearer $(\mathrm{S}>\mathrm{H})$ and the social distance is close (SD+) - since the Asian females has been working in the cafeteria for a relatively long time and have a close relationship with the participants. The final social variable is the degree of imposition and it is low (D-), the data was naturally controlled for these social variables. At the time of the data collection, there were two Asian women working in the cafeteria of the governmental institute. They were both from Nepal and were aged 30-40. For the purposes of this study they have been referred to as Beth and Sonia. In addition to their mother tongue, Nepali, they also speak English. As can be seen from the data, they were communicating with the study participants in Saudi Pidgin Arabic (SPA) and English. 


\subsection{Transcription}

One of the challenges in the transcription of the examples form the data is the choice of orthography used to represent spoken Arabic. Firstly, there is the obvious difference between Arabic and Roman orthography symbols (Al-Moaily, 2008). Secondly, the direction of writing is different in English (left to right) and in Arabic (right to left). These differences can be problematic because the glosses and the interpretation should be both written from left to right and are also supposed to be exactly under each word. To overcome these issues, and as suggested by Al-Moaily (2008), a four-part structure for the examples was used to represent the data. The first line of each example has been written in Arabic, followed by a second line of transliteration in Roman script. The third line includes interlinear glossing in a right-to-left direction and an English paraphrase for the Arabic sentence is given in the fourth line.

\section{Analysis and Discussion}

The following discussion focuses on the most significant features of SPA found in the elicited data. As mentioned, since the subjects of the current study were Saudi women, the analysis only includes the variety of SPA used by female native speakers of Saudi Arabic. The analysis focuses on the most distinctive characteristics that are related to the linguistic and grammatical systems of a number of elements: the noun phrase, the verb phrase, affixation, the copula fii, pronouns and demonstrative pronouns, and lexical features.

Additionally, the analysis provides a sociolinguistic perspective on politeness behaviour in making requests to female Asian workers.

\subsection{The Verb Phrase}

This section focuses on the general features of the verbal system of SPA and provides the differences and similarities between the same feature in SPA and its lexifier (Najdi Arabic, which is spoken by Saudis who live in the middle region of Saudi Arabia). This section also focuses on the elements systematically associated with the verb: tense, aspect, modality and mood.

\subsubsection{The Verb}

Previous research has found that the use of verbs in SPA is limited. When they do occur, they are usually employed as imperfect or imperative verbs in a predicate structure with a lack of tense, aspect or mood markers (Wiswall, 2002; Al-Azraqi, 2010). In Najdi Arabic, on the other hand, the verbal system is complex and the use of verbs is subject to systematic grammatical variation. According to Wiswall (2002) who discusses Gulf Arabic (a variety that is very similar to Najdi Arabic), the grammatical forms of verbs can usually be preffixed or suffixed by different object clitics. In line with Wiswall (2002) and Al-Azraqi (2010), the current study shows that the verb in SPA is mostly used in its simplified form, without any markers for tense and aspect or agreement in gender, number or person with the subject. Amongst the most common verbs employed in the elicited data were: $y$-bgha with a variant yibee 'want' ( $3^{\text {rd }}$ sing. masc. imperfect); sawwii 'make' ( $2^{\text {nd }}$ sing. fem. imperative); y-jeeb 


\section{Macrothink}

'bring' ( $3^{\text {rd }}$ sing. masc. imperfect); jeeb 'bring' ( $2^{\text {nd }}$ sing. masc. imperative) and jeebii 'bring' $\left(2^{\text {nd }}\right.$ sing. fem. imperative). Consider the following example:

(1)

\begin{tabular}{|c|c|c|c|c|}
\hline جبنة & كرواسون & واحد & يبغى & أنا \\
\hline jubnah & crowason & wahid & yibgha & ana \\
\hline cheese & croissant & one & he wants & I \\
\hline
\end{tabular}

I want one cheese croissant.

As can be seen from the data, the imperfect verb yibgha that has the prefix /y-/ (indicating $3^{\text {rd }}$ sing. masc. subject) in Najdi Arabic is used in SPA, instead of the Najdi Arabic verb a'bgha, which includes the first-person singular subject prefix / $a-/$. This supports the argument of Bakir (2010), who believes that the verbal form in Gulf Pidgin Arabic is frozen and is used in all sentences without agreement with the subject's gender or number. According to Bakir (2010), the same verb form can be used across different time and subject references.

Nevertheless, the use of verbs in SPA is unstable, which means that two forms of a verb can be used alternatively within the same conversation by the same speaker. Consider the following example:

(2)

\begin{tabular}{|c|c|c|c|c|}
\hline جيب كيس & بعدين & زبادي & يجيب & إنتي \\
\hline kees jeeb & ba'deen & zabadii & $y$-jeeb & entii \\
\hline bring & later & yogurt & bring & you \\
\hline $\begin{array}{l}\left(2^{\text {nd }} \text { sing. masc. }\right. \\
\text { imperative })\end{array}$ & & & $\begin{array}{l}\text { ( } 3^{\text {rd }} \text { sing. masc. } \\
\text { imperfect) }\end{array}$ & $\begin{array}{l}\left(2^{\text {nd }} \operatorname{sing} .\right. \\
\text { fem. pro) }\end{array}$ \\
\hline
\end{tabular}

You bring the yogurt then bring the bag.

As can be seen from the conversation, the speaker employs the verb 'bring' with different inflections $\left(2^{\text {nd }}\right.$ sing. masc. imperative and 3rd sing. masc. imperfect). In fact, the data from this study support the claims of Bakir (2010) that the instability in the use of verbs in GPA is due to some of the linguistic features of its lexifier (Gulf Arabic). For instance, the imperfect verb stem in Gulf Arabic without the prefix /y-/ refers to the imperative of $\left(2^{\text {nd }}\right.$ sing. masc. 


\section{Macrothink}

imperative) (Bakir, 2010). Consider the following verbs that were taken from data in the current study:

Imperatives

Imperfects

jeeb

(you) bring

y-jeeb

he brings

sawii

(you) make

$y$-sawwii

he makes

Bakir (2010) believes that variability in verb use is a source of confusion amongst non-native speakers of Arabic, so the use of verbs in such a way by native Arab speakers might result from imitating the Asian workers as a means of simplifying the language. However, Salem (2013) claims that multifunctionality is a feature of the use of verbs in Kuwaiti Pidgin Arabic (KPA, which also falls under the umbrella of Gulf Pidgin Arabic) is a result of the limited vocabulary and the lack of inflections. Since the current study only includes the speech of Saudi females, it can be said that the results seem to be consistent with the suggestions of both Bakir (2010) and Salem (2013).i.e. imitating the Asian workers as a means of simplifying the language in addition to the limited vocabulary system in the SPA.

The following section provides a more detailed discussion of tense, aspect and mood (TAM) markers in SPA as used in the data of the current study.

\subsubsection{Tense and Aspect}

One of the distinctive features of SPA is the absence of tense and aspect markers, meaning that the same form of one verb is often used to represent two different tenses. Consider the following examples:

(3)

\begin{tabular}{|c|c|c|c|}
\hline مفرود؟ & خبز & سوي & مافي \\
\hline mafroud & khubuz & sawwii & mafii \\
\hline $\begin{array}{l}\text { Lebanese } \\
\text { (bread) }\end{array}$ & bread & $\begin{array}{l}\text { make } \\
\left(2^{\text {nd }} \text { sing. fem. }\right. \\
\text { imperative })\end{array}$ & $\begin{array}{l}\text { there no } \\
\text { (negation, copula) }\end{array}$ \\
\hline
\end{tabular}

Why did (you) not make Lebanese bread? 


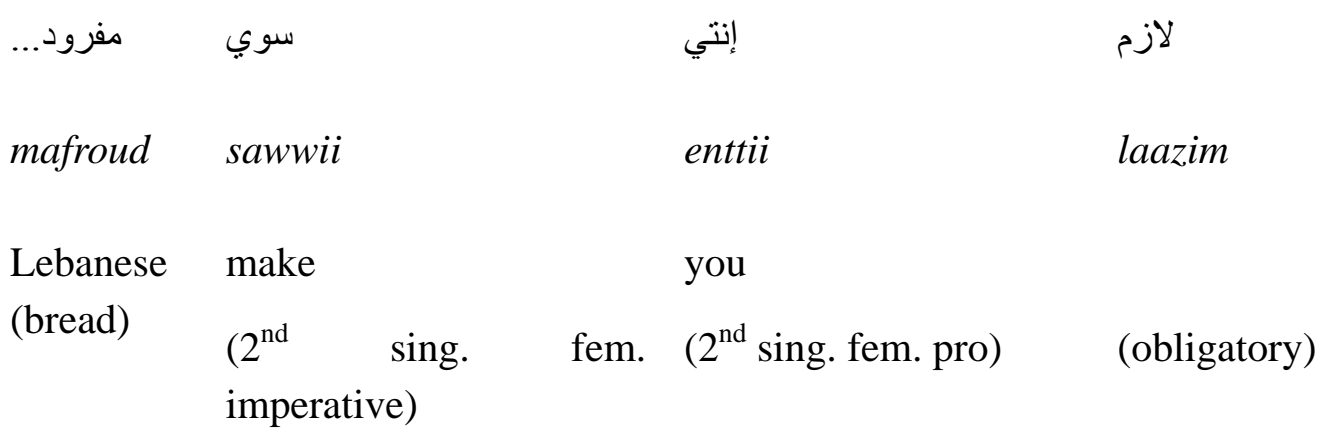

You have to make Lebanese (bread) (sandwich)....

As can be seen in examples 3 and 4, the only way to determine the tense and aspect of the verb is to consider the context of the conversation. This finding is consistent with those of Al-Azraqi (2010), Al-Moaily (2008), Salem (2013), and Smart (1990) in relation to the frozen morphosyntactic structure and context-dependence in the interpretation of SPA verbs.

\subsubsection{Modality}

The modality system in SPA is derived from its lexifier (Najdi Arabic), which exhibits a wide range of modal forms (Bakir, 2010). In both of these varieties, modality is communicated through independent forms that are expressed as participles or verbs and are characterized by their limited grammatical use. The lexical items involved in the expression of modality maintain a functional status regardless of their lexical content (Bakir, 2010). For example, necessity or obligation in SPA was only expressed in the current data by the form laazim 'obligatory', as in example (4) above, while possibility was expressed by the form mumkin 'possible', as in example (5) below.

(5)

\begin{tabular}{|c|c|c|}
\hline الحليب.... & ت ت ت تخنين & 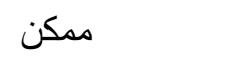 \\
\hline el haleeb... & tisakhneen & mumkin \\
\hline he milk & heat ( $2^{\text {nd }}$ sing. fem. imperfect) & possibility) \\
\hline
\end{tabular}

Is it possible you heat the milk....

In addition to the participles laazim and mumkin, modality in SPA can be expressed using verbs. The verb yigdar 'can', for instance, was employed as follows by one of the participants in her requests for tea from the cafeteria worker:

(6) 


\begin{tabular}{|c|c|c|c|c|}
\hline شاهي & أنا & لي & يجيب & يقدر \\
\hline shahee & ana & lee & yijeeb & yigdar \\
\hline tea & me & for me & $\begin{array}{l}\text { bring }\left(3^{\mathrm{rd}} \text { sing. masc. }\right. \\
\text { present })\end{array}$ & $\begin{array}{l}\text { can }\left(3^{\text {rd }} \text { sing. masc. }\right. \\
\text { present })\end{array}$ \\
\hline
\end{tabular}

Can you bring me some tea?

\subsubsection{Mood}

Verbs in Arabic and its dialects have a wide range of mood variation. However, as in other pidgins, SPA shows a limited use of mood, and verb use is mainly restricted to either the imperative form as shown by Bakir (2010) and Bizri (2009), or imperfect verbs without prefixes that indicate the gender and the number of the subject or tense (Al-Azraqi, 2010). This is reflected in the participants' use the verbs sawwii (make) and yijeeb (bring), as in examples (4) and (6).

\subsubsection{Affixation}

In Classical Arabic and its dialects, verbs are usually distinguished by the prefixes and suffixes that are used to indicate the tense of the verb and the gender and number of the subjects (Smart, 1990; Al-Azraqi, 2010). The following are some forms of the verb sawii in Najdi Arabic when it is attached to different affixes.

\begin{tabular}{|c|c|c|c|c|}
\hline Verb & $\underline{\text { Prefix }}$ & $\underline{\text { Suffix }}$ & Tense & $\underline{\text { Subject }}$ \\
\hline sawwa & - & - & past & $3^{\text {rd }}$. sing. masc \\
\hline$s a w w$ & - & - & imperative & $2^{\text {nd }} \cdot \operatorname{sing}$. masc \\
\hline$y i-s a w w-i i$ & $y i-$ & $-i i$ & imperfect & $3^{\text {rd }}$. sing. masc \\
\hline$s a w w-a t$ & - & $-a t$ & past & $3^{\text {rd }}$. sing. fem \\
\hline$s a w w-i i$ & - & $-i i$ & imperative & $2^{\text {nd }} \cdot$ sing. fem \\
\hline$t i-s a w w-i i$ & $t i-$ & $-i i$ & imperfect & $3^{\mathrm{rd}} \cdot$ sing. fem \\
\hline
\end{tabular}

Nevertheless, the data shows that verbs such as sawwii 'make' are commonly used in SPA in their imperative forms in various contexts without affixation. This is evident in examples (3) and (4) above. 


\subsection{The Noun Phrase}

Before providing an analysis of noun phrases in SPA, it is important to discuss the most significant features that distinguish the noun phrase in Arabic, particularly in this variety (Najdi Arabic). In Arabic, the basic element for the predication structure (the noun phrase) is nominal sentences. These consist of the predicand, which provides the main theme of the sentence, and the predicate, which usually (but not always) comes after the predicands and includes information about the predicand (Al-Azraqi, 2010). Predicands in Arabic and in Najdi Arabic are usually definite and have several forms. These include personal or demonstrative pronouns, proper nouns or nouns with definite articles (Al-Azraqi, 1998; Al-Azraqi, 2010).

The data from this study show that the use of the predication structure in SPA is limited and inconsistent, unlike in Najdi Arabic. The following examples in SPA and Najdi Arabic were all taken from the data and all mean 'how are you?'. (Note that all interrogative tools in these expressions come as preceded predicates.)

(7)

(a)

$\begin{array}{lll}\text { Sيف } & \text { (النتي؟ } \\ \text { entii? } & \text { haal } & \text { keef }\end{array}$

you $\left(2^{\text {nd }}\right.$ sing. fem. pronoun $)$ condition how

How are you?

(b)

حالك؟

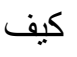

haalik?

keef

condition $+\left(2^{\text {nd }}\right.$ Sing. Fem. Personal. how Suffix)

How are you?

(c) 
كيفاك؟

keefik

how $+\left(2^{\text {nd }}\right.$ sing. fem. personal. suffix $)$ ?

How are you?

In example (7a), the participant uses SPA to greet the hearer and employs the interrogative tool (how) and a free pronoun (you). On the other hand, the expressions in examples (7b) and (7c) are commonly used in Najdi Arabic for greetings, the predication structures include the suffix $(-i k)$ that is usually used to address the second singular feminine person.

In addition, predication phrases have also been accomplished in the data of the current study through the use of the copula fii as follows:

(8)

$\begin{array}{lll} & & \\ \text { kwayes } & \text { mafii } & \text { ba'deen } \\ \text { good } & \text { (negation, copula) } & \text { then }\end{array}$

It will not be good then.

The use of copula fii extends to serve more functions in SPA. Hence, it will be the focus of the following section.

\subsection{The Copula Fii}

Both the current study and other studies found that one of the prevalent features of SPA is the use of the copula fii (Smart, 1990; Al-Moaily, 2008; Wiswall, 2002; Salem, 2013). As claimed by Wiswall (2002), the copula fii in Gulf Pidgin Arabic (GPA) is not only prevalent, but is overused and considered a major feature. Since Najdi Arabic is the lexifier of SPA, it is important to provide an understanding of the copula and its main characteristics in both varieties (Najdi Arabic and SPA). Firstly, the copula in Najdi Arabic has the following features (Al-Moaily, 2008).

In the past tense, the copula (kan +subject agreement) is as follows:

Mona $\quad$ maridah ams


Mona

past.cop+agr.fem

sick

yesterday

Mona was sick yesterday.

In the present tense, Najdi Arabic is a null copula:

hu tabeeb

pro.3p.sing.masc. doctor.masc.

He is a doctor.

In the future tense, the copula in Najdi Arabic is represented by the prefix $b$ or the lexical term $r a h$ as future markers.
Ali
bykoon/rah yekoon hina
Ali
fut.cop.sub.agr
here

Ali will be here.

Additionally, the inflection system is rich in Najdi Arabic and there is an agreement between the copula and the subject for number, person and gender (Al-Moaily, 2008).

The copula in SPA, on the other hand, has less complexity and the inflection system is more simplified than in Najdi Arabic (Al-Moaily, 2008). It is represented by the element fii, which serves various functions according to the context. The copula fii is borrowed from Arabic (the lexifier of SPA) and as in English, fii, together with its negative form mafii are both used to serve the meanings of 'there is', 'is there?' and 'there is not', in addition to the meaning of the preposition 'in' in Najdi Arabic (Bakir, 2010). The following examples were taken from the data:

$\begin{array}{lll} & \text { فيب اليومج } & \text { في } \\ \text { elyoum? } & \text { haleeb } & f i i \\ \text { today? } & \text { milk } & \text { there }\end{array}$


(10)

$\begin{array}{llll}\text { Mafii? } & \text { sandwich? } & \text { fii } & \text { eash } \\ \text { there no? } & \text { sandwich? } & \text { there } & \text { what }\end{array}$

What kind of sandwiches are there? There aren't (any)?

As can be seen, in examples (9) and (10), the various forms of the copula are used to represent both 'there is' and 'there are not'.

Furthermore, the copula fii is considered to be a verb in some contexts (Smart, 1990) for two reasons: it is used before adjectives and nouns in equational sentences, and it is used before the main verb to form a compound verb. Consider the following examples that were taken from the data:

\begin{tabular}{|c|c|c|c|}
\hline سيم سيخ؟ & مافي & 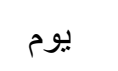 & كل \\
\hline same same? & mafii & youm & kull \\
\hline $\begin{array}{l}\text { the same } \\
\text { (adj.) }\end{array}$ & $\begin{array}{l}\text { there no there no (negation, } \\
\text { copula) }\end{array}$ & day & every \\
\hline
\end{tabular}

The same (food) is not available every day?

(12)

\begin{tabular}{|c|c|c|c|c|}
\hline أنشتري & في & إيش & أشوف & أنا \\
\hline a'shtrey & fii & eash & ashouf & ana \\
\hline $\begin{array}{l}\text { Buy ( } 1^{\text {st }} \text { sing. } \\
\text { present })\end{array}$ & there (copula) & what & $\begin{array}{l}\text { see }\left(1^{\text {st }} \text { sing. }\right. \\
\text { imperfect })\end{array}$ & $\begin{array}{l}\text { I (1st } \\
\text { sing. } \\
\text { pronoun) }\end{array}$ \\
\hline
\end{tabular}

I will look (and decide) what I will buy.

In Example (11), the speaker (a study participant) asks the hearer (the cafeteria worker) if they serve the same food every day, while in Example (12), the speaker requests that hearer 


\section{Macrothink}

bring chocolate bars so she can decide what to buy. As we can see, the copula fii is used in conjunction with the adjective 'the same' in Example (11) and is used in conjunction with the verb 'buy' in Example (12).

Other researchers provide different definitions for the copula fii. Al-Azraqi (2010), for instance, defines the copula $f i$ (or fii as transcribed here) as a particle since it serves various functions in sentences. Besides the functions already mentioned here, Al-Azraqi (2010) claims that the particle $f i$ (fii) functions as a possessive pronoun. In the following example, taken from the data from older participants, the copula fii is employed to serve such a function:

$\begin{array}{llll}\text { kees... } & \text { fii } & \text { ana } & \text { Beth } \\ \text { bag } & \text { there (copula) } & \text { I (1st sing. pro) } & \text { Beth }\end{array}$

Beth, I have a bag.....

While Naess (2008) argues that the use of copula fii is rare in GPA, the data of the current study supports the claims of Al-Azraqi (2010) and Smart (1990) regarding the concept of this use of the copula fii. As can be seen from the examples, participants included fii and its negation in various contexts.

The data analysis shows that in addition to fii, demonstrative pronouns also can function as a copula in SPA as in the following example:

$\begin{array}{lll}. . . .4 & \text { أنا } \\ \text { maktab } & \text { hatha } & \text { ana } \\ \text { office.... } & \text { this } & \text { I } \\ \text { I am in (the) office... } & \end{array}$

The following section focuses on the use of pronouns and demonstrative pronouns in SPA.

\subsection{Pronouns and Demonstrative Pronouns}

As previously mentioned, each recorded conversation took place between two women (the participant and the cafeteria worker). Thus, the only pronouns that should have been 


\section{Macrothink}

Business Management and Strategy

ISSN 2157-6068 2015, Vol. 6, No. 1

employed in the conversations were: أنا ana 'I' (1 $1^{\text {st }}$ sing. pronoun) and entii 'you' (2 sing. pronoun). In fact, although some studies show more use of pronouns in SPA and GPA, it can be said that these varieties are still limited and have not yet achieved a systematic use of pronouns and other lexical features (Al-Azraqi, 2010).

The data show that free pronouns were employed to serve the function of the suffixes or the bound pronouns such as /-ik/, discussed in example (7), and /-ii/, as follows:

(a)

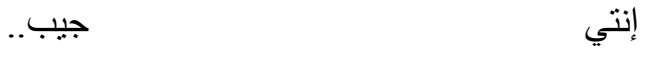

jeeb entii

bring $\quad\left(2^{\text {nd }} \quad\right.$ sing. masc. you $\left(2^{\text {nd }}\right.$ sing. fem. pro $)$

imperative)

(b)

$$
\begin{aligned}
& \text { جيبي } \\
& \text { jeebii } \\
& \text { bring ( } \left.2^{\text {nd }} \text { sing. fem. imperative }\right)
\end{aligned}
$$

You bring.

(a)

أنا

ana

I ( $1^{\text {st }}$ sing. pro $)$

(b) 
maktabii

office $+\left(2^{\text {nd }}\right.$ sing. fem. personal. suffix $)$ ?

My office.

(c)

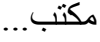

maktab

office....
هذا

hatha

this
أنا

ana

I ( $1^{\text {st }}$ sing. pro $)$

I am in (the) office...

While both examples stand for 'you bring', the free pronoun entii in Example (15a) employed by the participant in SPA serves the function of the suffix, i.e. the bound pronoun (-ii) in Najdi Arabic, in the same verb in example (15b) employed in Najdi Arabic. Additionally, as shown in examples (16a) and (16b), free pronouns in possessive expressions in SPA are used in place of bound pronouns that come as suffixes with nouns in noun phrases. The results of the current study support the results of Al-Azraqi (2010), who claims that one of the main reasons for the prevalent use of free pronouns is the limited use of bound pronouns in pidgin varieties. The data show that the use of demonstrative pronouns in SPA is limited and not consistent with the use of such pronouns in Najdi Arabic. For instance, the demonstrative pronoun s hatha 'this' was employed in example (16c) as a copula in SPA and this function does not exist in its lexifier (Najdi Arabic). Moreover, as in Al-Azraqi (2010), the use of demonstrative pronouns in GPA did not indicate gender or plurality.

Further features of SPA lexical items will be discussed in the following section.

\subsection{Lexical Features}

It is important to focus on some of the lexical features that distinguish SPA. Based on the data of the current study, the following discussion focuses on the use of English vocabulary and repetition in this variety.

\subsubsection{Borrowing from English}

One of the most significant features in SPA is the lack of a unified vocabulary system. The use of English words, hence, is common in the conversations between native speakers of Saudi Arabic and the speakers of Asian languages (Salem, 2013). The following example is a request by one of the participants: 
(17)

\begin{tabular}{|c|c|c|c|}
\hline $\begin{array}{l}\text { chicken } \\
\text { sandwich }\end{array}$ & واحد & أبغى & لو سمحتي \\
\hline & wahid & abgha & law samahtii \\
\hline & one & want $\left(1^{\text {st }}\right.$ sing. imperfect) & if you permit \\
\hline
\end{tabular}

Excuse me, I want one chicken sandwich.

For the same reason - lexical limitations - the data also show that other English words such as yes, no, okay and Latin numbers are also commonly used in SPA. (See also section 4.6 below for more detail.)

\subsubsection{The use of adjectives}

Adjectives in most, if not all, dialects of Arabic agree with nouns in all grammatical aspects. When they are used in sentences they agree with their nouns in gender, number, and in definition (Smart, 1990). However, as claimed by Smart (1990), adjectives in GPA are typically used without the definite article and are employed in their masculine form. The data from the current study supports the findings of Smart (1990), showing that there is a lack of agreement between adjectives and their nouns in SPA. The following examples were taken from the data:

كويس؟

kwayes?

$\operatorname{good}($ sing. masc. adj)

How are you? Good?

\section{كيفاك؟}

Keefik?

how are you $\left(2^{\text {nd }}\right.$. sing. pro+ fem. suffix $)$ ?

\begin{tabular}{|c|c|c|c|c|}
\hline أصفر & جبنة & واحد & لي & جيبي \\
\hline asfar & jubnah & wahid & $l i i$ & jeebil \\
\hline
\end{tabular}




$\begin{array}{lllll}\text { yellow } & \text { cheese } & \text { one } & \text { for } & \text { bring } \\ \text { (sing. masc. } & \text { (uncount. fem. } & \text { (sing. masc. } & \text { me } & \left(2^{\text {nd }} \text { sing. fem. }\right. \\ \text { adj) } & \text { noun }) & \text { adj }) & & \text { imperative })\end{array}$

Bring me one yellow cheese (sandwich).

$\begin{array}{llll} & \text { فينة } & \text { ساندوينش } & \\ \text { beeda } & \text { jubnah } & \text { sandwich } & \text { fii } \\ & \text { cheese } & \text { sandwich } & \text { there } \\ \text { white } & \text { (uncount. fem. noun) } & \text { (uncount. fem. noun) } & \text { (copula) }\end{array}$

Are there any white cheese sandwiches?

In Examples (18) and (19), the participants employ adjectives in SPA that stand for 'good' and 'yellow' and they do not agree with their nouns. However, the participant in Example (20) uses the adjective 'white' in Najdi Arabic with gender agreement.

The Arabic language is characterized by the use of repetition for various purposes such as emphasizing or providing more explanation. For instance, the participant in Example (11) employs the adjective (same) in her request with repetition. This feature also supports the findings in the study of Smart (1990), who provides a wider classification of repetition features in GPA to include adjectives, nouns and adverbs.

\subsubsection{Negation}

One of the most frequent markers used by the participants was the prefix /ma-/, a negation particle in spoken Saudi Arabic, together with the copula fii to indicate negation in their conversations. Consider the following:

(a) مشكلة<smiles>[AlH2]</smiles>

mushkilah

mafii

problem (noun)

there no (negation. copula) 
There is no problem.

كويس (b)

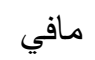

kwayees

mafii

good (adjective)

there no (negation. copula)

Not good.

سوي (c) - (2)

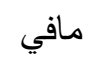

sawwii

mafii

make (verb)

there no (negation, copula)

Don't/didn't make...

As the data indicate, the same formula is used to negate nouns, adjectives and verbs. In addition, the participants employed the negation particle /ma-/ in other contexts as a prefix with the main verb as follows:

(22)

مايجيب؟

Ma yi-jeeb?

Did not bring

( $3^{\text {rd }}$ sing. masc. negated. imperfect)
تبولة؟

taboolah fii

taboolah there is (copula)
بيث

Beth

Beth

Beth, is there (any) taboolah? You did not bring (it)?

The alternative use of negation markers /ma-/ and mafii in SPA is very similar to the use of the same strategy in GPA (Bakir, 2010).

\subsubsection{Numerals}

The data show that the participants employed a few numerical expressions in their conversations. Consider the following examples that were taken from the data: 


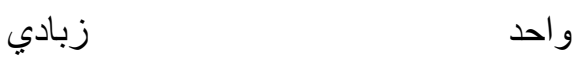

zabadii

wahid

yougurt (masc. noun)

one (sing. masc. adj)

One yogurt

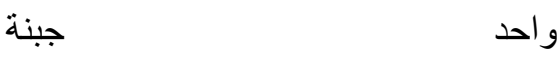

jubnah wahid

cheese (fem. noun) one (sing. masc. adj)

One cheese (sandwich)

$\begin{array}{ll} & \text { مرة } \\ \text { thanii } & \text { time }\end{array}$

second (sing. masc. adj) time (sing. fem. noun)

Second (next) time

While the use of numerals in Najdi Arabic is subject to a systematic order and agreement in gender in its cardinal, dual and plural forms, the use of the same linguistic feature in SPA is simplified and does not follow the same syntactic rules of its lexifier. In Examples (23) and (24), for instance, the use of number 'one' to describe both feminine and masculine nouns is expressed by the adjective وحدة, wahdah 'one' is used to describe (sing. fem. noun) in Najdi Arabic.) Furthermore, example (25) shows that the participant employs a simplified form of the adjective 'second' that does not agree with the noun.

As in Smart (1990), some participants employed English expressions to express ordinals. This tendency also suggests that there may be a limitation and a lack of a suitable numbering system in SPA. The following example was employed by one of the participants:

number one four seven

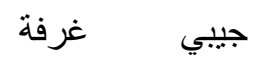


gurfah jeebii

room bring $\left(2^{\text {nd }}\right.$ sing. fem. imperative $)$

Bring (it) to room number one four seven.

Sociolinguistic issues related to requests from non-native workers will be discussed in the following section.

\subsection{SPA from a Sociolinguistic Perspective}

In this study, all participants used direct strategies when making requests. One of the reasons was because that the status of the speaker is higher than the hearer and the other reason was because the degree of imposition was low, i.e. ordering breakfast. In addition, the participants employed various internal and external modifications. As in the requests in both social and work contexts, they used interrogatives and politeness markers such as: mumkin? 'is it possible?' and law samahtii, 'would you mind'. Furthermore, the data show that some of the older participants used religious expressions, such as invocations and Islamic greetings, in their requests, such as Assalam aliakom 'peace be upon you'. This behaviour, as claimed by Al-Qahtani (2009), can be interpreted as a means of showing intimacy between the interlocutors. Use of small talk is the most frequent external modification that was employed in the data, as in example (27):

$$
\text { الو مين؟ سونيا؟ كيفك؟ كويس؟ في حليب اليو ج؟ }
$$

Aalloo meen? Sonia? Keefik? Kwayes? Fee haleeb elyoom?

Hello, who is this? Sonia? How are you? Good? Is there any milk for today?

The use of SPA amongst Saudi women also included terms such as kwayes, 'good' and tayeb, 'okay/that's fine' in most conversations. The use of these linguistic modifications might be similarly interpreted as ways of showing closeness and friendly behaviour between the speaker and the hearer.

As mentioned earlier, the data were collected by recording two generations of Saudi women. One of the reasons for choosing two different age groups was to determine whether age had an impact when using SPA to interact with non-native Arabic speakers or not. Consider the following examples:

How are you Beth? 
I'm fine thank you. Beth can you please send me two teas upstairs?

And can you also... Do you have cheese fatayer (pies)?

Okay can I also have one cheese fatayer (pie)?

Just one and make the tea three please.

Ya three tea and one fatayer (pie) please.

Okay, thank you.

$$
\text { كيف حال أنتي؟ كويس؟ سونيا في فلافل؟ طيب ابغى واحد فلافل. }
$$

Keef hal entii? Kwayias? Sonia fii falafel? Tayeb abgha wahed falafel.

Tayeb fii tuna? Tayeb ana hatha ghurfah 147.

Falafel wu tuna wu hummus wu mutabbal fii? Mafii mutabbal? Tayeb baba ghannooj fii?

Tayeb abgha wahed hummus wu wahed mutabbal wu wahed tuna wu seven up bas seven up jeebii e'ssa'ah than'ash, mumkin?

Tayeb shukran.

"How are you? Good?

Sonia, do you have falafel?

Ok, I want one falafel. Ok, do you have tuna?

Ok, I'm in room (number) 147.

Falafel and tuna and hummus and do you have mutabbal?

There is no mutabbal? That's fine, so do you have baba ghannooj?

That's fine, I want one hummus and one mutabbal and one falafel and one tuna and Seven Up, but for the Seven Up bring it at 12 o'clock, okay?

Ok, thanks."

As can be seen in Example (28), the younger participant employs English in the whole conversation (apart from the word fatayer (pie), while the older participant in Example (29) 
employs both Arabic and SPA in her request to the cafeteria worker. In fact, the growing use of English in several sectors of the Saudi educational system and modern technology such as cell phones and computers is an obvious reason for the wide use of English words and expressions amongst the younger generations.

By focusing on sociolinguistic dimensions, it can be said that the use of SPA reflects one of the social features that distinguishes communities in Gulf countries. According to Bakir (2010), the reduced system of communication shows that there is a wide social distance between the two groups, i.e. Gulf Arabic speakers and migrant workers from other Asian countries. This situation means that newcomers from those countries do not learn the language of the new country and do not become members of the new culture. The continual flow of workers who only stay for a limited period of time, and who find it easier to communicate in a simple and specific language variety, is another reason that has created the need for SPA and other Gulf pidgins.

\section{Conclusion}

This study examined requests performed by two generations of Saudi women in contact with non-native speakers of Arabic, using Saud Pidgin Arabic (SPA).

Based on an analysis of the data, this variety has some specific linguistic features related to both verb and noun systems. The use of verbs in SPA is limited and restricted to the simplest forms of verbs in most contexts. In addition, the use of verbs in SPA is also not subject to the rules of the verbal system in Najdi Arabic, the lexifier language of SPA. The verb tense, aspect, mood and modality and other components of verbs are often used in a way that does not reflect their exact features and their exact meanings, and tense is usually determined from the context of the interaction. Although there are systematic rules for affixation in Najdi Arabic, the same linguistic feature is not applied in most contexts of verb phrases in SPA. Instead, the speakers tend to use the same verb in various contexts to serve different functions.

The most significant feature that distinguishes the use of noun phrases in SPA is that they do not follow the systematic features of a noun phrase in Najdi Arabic. Because of the reduction of the noun phrase in SPA, the speakers employ markers such as free pronouns to serve functions that differ from functions in the lexifier, Najdi Arabic.

Another noticeable feature in SPA is the use of the copula fii. As found by Smart (1990) and Bakir (2010), the use of fii has become a dominant characteristic of this variety. This wide use of fii and its form of negation mafii is another consequence of the reduction in the linguistic system (Bakir, 2010). The analysis shows that there are also some lexical features, such as borrowing from English, the use of adjectives, repetition, negation and the use of numeric expressions that have been developed, modified or simplified.

The use of SPA amongst two generations shows that the younger generation tended to employ more English expressions in SPA as a result of the increasing impact of English on younger 
generations. Another important issue that has arisen from the data is that the use of SPA reflects the wide social distance between Asian migrant workers and their employers in Saudi Arabia.

Finally, the corpus for this study was restricted to the speech of Saudi native speakers of Arabic, which justifies the need to investigate the spoken form of SPA that is usually used by non-native speakers of Saudi Arabic from other Asian nationalities. Nevertheless, it is important to mention that this study is significant because it contributes in filling the gap in the literature in relation to socio-pragmatic and sociolinguistic perspectives.

\section{Acknowledgement}

The research is financed by The Institute of Public Administration, Riyadh, Saudi Arabia. Thanks for:

Desmond Cahill, Professor of Intercultural Studies, School of Global, Urban and Social Studies, RMIT University, Melbourne.

Dr Kerry Mullan, Senior Lecturer, Coordinator French Studies, Language Studies, School of Global, Urban and Social Studies

RMIT University

\section{References}

Al-Azraqi, M. (1998). Aspects of the Syntax of the Dialect of Abha (Southwest Saudi Arabia). PhD Thesis, University of Durham, Durham, UK.

Al-Azraqi, M. (2010). Pidginisation in the eastern region of Saudi Arabia: Media presentation. In Reem Bassiouney (Ed.), Arabic and the Media: Linguistic analyses and applications (pp. 159-173).

Al-Gahtani, S. (2010). Requests made by L2 learners of Arabic: Pragmatic development, methodological comparison, and politeness. Unpublished doctoral thesis, Melbourne University, Victoria, Australia. [Online] Available: http://portal.ksu.edu.sa/sites/default/files/PhD\%20Thesis_0.pdf

Al-Moaily, M. (2008). A Data-Based Description of Urdu Pidgin Arabic. Unpublished MA dissertion, Newcastle University.

Al-Qahtani, H. (2009). Female use of politeness strategies in the speech act of offering: A contrastive study between spoken Saudi Arabic and spoken British English. Unpublished M.A thesis, King Saud University, Riyadh, Saudi Arabia.

Bakir, M. (2010). Notes on verbal system of Gulf Pidgin Arabic. Journal of Pidgin and Creole Languages, 25(2). 201-228. http://dx.doi.org/10.1075/jpcl.25.2.01bak

Beebe, L. M., \& Cummings, M. C. (1996). Natural speech act data versus written questionnaire data: How data collection method affects speech act performance. In S. M. 
Gass \& J. Neu (Hg.), Speech Acts across Cultures. (pp. 65-86). Berlin: Mouton de Gruyter. (Original version 1985).

Bickerton, D. (1983). Creole Languages. Scientific American, 249(8), 116-122. http://dx.doi.org/10.1038/scientificamerican0783-116

Bizri, F. (2009). Sinhala in contact with Arabic: The birth of a new pidgin in the Middle East. Annual Review of South Asian Languages and Linguistics, Rajendra Singh (Ed.). 135-149. Berlin and New York: Mouton de Gruyter.

Blum-Kulka, S., House, J., \& Kasper, G. (1989). Investigating cross-cultural pragmatics: An introductory overview. In S. Blum-Kulka, J. House, \& G. Kasper (Eds.), Cross-cultural Pragmatics: Requests and apologies (pp. 1-34). Norwood, NJ.

Boxer, D. (1993). Complaining and commiserating: A Speech act view of solidarity in spoken American English. Peter Lang New York.

Brown, P., \&Levinson, S. (1987). Politeness: Some universals in language usage. Cambridge: Cambridge University Press.

Félix-Brasdefer, J. (2005). Indirectness and politeness in Mexican requests. In David Eddington (Ed.), Selected Proceedings of the 7th Hispanic Linguistics Symposium (pp. 66-78). Somerville, MA: Cascadilla Proceedings Project.

Ferguson, C. (1971). Absence of copula and the notion of simplicity: A Study of normal speech, baby talk, foreigner talk, and pidgins. In Dell Hymes (Ed.), Pidginization and Creolization of Languages (pp.141-150). New York: Cambridge University Press.

Hartford, B. S., \& K. Bardovi-Harlig. (1992) Experimental and observational data in the study of interlanguage pragmatics. In L. Bouton, \& Y. Kachru (Eds.), Pragmatics and Language Learning, Monograph 3 (pp. 33-52). Urbana-Champaign, IL: DEIL

Naess, U. (2008). Gulf Pidgin Arabic: Individual strategies or structured variety. MA thesis: University of Oslo.

Roberts, S., \& Bresnan, B. (2008). Retained inflectional morphology in pidgins: A typological study. Linguistic Typology, 269-302. http://dx.doi.org/10.1515/LITY.2008.039.

Salem, A. A. (2013). Linguistic Features of Pidgin Arabic in Kuwait. English Language Teaching, 6(5). 105-110.

Smart, R. J. (1990) Pidginisation in gulf Arabic: a first report. Anthropological Linguistics, 2(1- 2). 83-119. [Online] Available: http://www.jstor.org/stable/30028141?seq=1\#page_scan_tab_contents

Tran, G. Q. (2004). Revisioning methodologies in cross-cultural and interlanguage pragmatics. English. Edu: Journal of Language Teaching and Research, 4(1), 25-49. 


\section{Macrothink}

Business Management and Strategy ISSN 2157-6068 2015, Vol. 6, No. 1

Wiswall, A. (2002). Gulf pidgin: An expanded analysis. Unpublished paper. University of Ohio, Linguistic Department.

\section{Copyright Disclaimer}

Copyright for this article is retained by the author(s), with first publication rights granted to the journal.

This is an open-access article distributed under the terms and conditions of the Creative Commons Attribution license (http://creativecommons.org/licenses/by/3.0/). 